\title{
Lack of drug-induced post-retrieval amnesia for auditory fear memories in rats
}

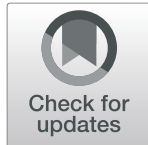

Laura Luyten ${ }^{1,2^{*}}$, Anna Elisabeth Schnell ${ }^{1,2}$, Natalie Schroyens ${ }^{1,2}$ and Tom Beckers ${ }^{1,2}$

\begin{abstract}
Background: Long-term memory formation is generally assumed to involve the permanent storage of recently acquired memories, making them relatively insensitive to disruption, a process referred to as memory consolidation. However, when retrieved under specific circumstances, consolidated fear memories are thought to return to a labile state, thereby opening a window for modification (e.g., attenuation) of the memory. Several interventions during a critical time frame after this destabilization seem to be able to alter the retrieved memory, for example by pharmacologically interfering with the restabilization process, either by direct protein synthesis inhibition or indirectly, using drugs that can be safely administered in patients (e.g., propranolol). Here, we find that, contrary to expectations, systemic pharmacological manipulations in auditory fear-conditioned rats do not lead to druginduced post-retrieval amnesia.

Results: In a series of well-powered auditory fear conditioning experiments (four with propranolol, $10 \mathrm{mg} / \mathrm{kg}$, two with rapamycin, 20-40 mg/kg, one with anisomycin, $150 \mathrm{mg} / \mathrm{kg}$ and cycloheximide, $1.5 \mathrm{mg} / \mathrm{kg}$ ), we found no evidence for reduced cued fear memory expression during a drug-free test in adult male Sprague-Dawley rats that had previously received a systemic drug injection upon retrieval of the tone fear memory. All experiments used standard fear conditioning and reactivation procedures with freezing as the behavioral read-out (conceptual or exact replications of published reports) and common pharmacological agents. Additional tests confirmed that the applied drug doses and administration routes were effective in inducing their conventional effects on expression of fear (propranolol, acutely), body weight (rapamycin, anisomycin, cycloheximide), and consolidation of extinction memories (cycloheximide).

Conclusions: In contrast with previously published studies, we did not find evidence for drug-induced postretrieval amnesia, underlining that this effect, as well as its clinical applicability, may be considerably more constrained and less readily reproduced than what the current literature would suggest.

Keywords: Fear conditioning, Auditory fear, Rats, Post-retrieval amnesia, Reconsolidation, Consolidation, Propranolol, Rapamycin, Anisomycin, Cycloheximide
\end{abstract}

\footnotetext{
* Correspondence: laura.luyten@kuleuven.be

${ }^{1} \mathrm{KU}$ Leuven, Faculty of Psychology and Educational Sciences, Psychology of Learning and Experimental Psychopathology, Tiensestraat 102 PB 3712, 3000 Leuven, Belgium

${ }^{2}$ Leuven Brain Institute, Herestraat 49 PB 1021, 3000 Leuven, Belgium
}

(C) The Author(s). 2021 Open Access This article is licensed under a Creative Commons Attribution 4.0 International License, which permits use, sharing, adaptation, distribution and reproduction in any medium or format, as long as you give appropriate credit to the original author(s) and the source, provide a link to the Creative Commons licence, and indicate if changes were made. The images or other third party material in this article are included in the article's Creative Commons licence, unless indicated otherwise in a credit line to the material. If material is not included in the article's Creative Commons licence and your intended use is not permitted by statutory regulation or exceeds the permitted use, you will need to obtain permission directly from the copyright holder. To view a copy of this licence, visit http://creativecommons.org/licenses/by/4.0/ The Creative Commons Public Domain Dedication waiver (http://creativecommons.org/publicdomain/zero/1.0/) applies to the data made available in this article, unless otherwise stated in a credit line to the data. 


\section{Background}

Consolidated memories have long been seen as immutable, but accumulating evidence suggests that they are not set in stone and that they can still be modified or even erased after the completion of synaptic consolidation $[1,2]$. This paradigm shift was first proposed in the late 1960s [3] and received important support 20 years ago $[4,5]$. These studies suggested that interventions such as an electroconvulsive shock or drug administration into the basolateral amygdala shortly after reactivation of the memory allowed for interference with this memory in such a way that there was a significant attenuation of memory expression (i.e., amnesia) on subsequent testing. It is not within the scope of this paper to give a comprehensive overview of all these findings (for a review, see e.g., [6]), but it is safe to say that many of these studies have put forward that this technique could be a game changer in the treatment of several types of psychopathology in which maladaptive memories are a core feature, e.g., post-traumatic stress disorder (PTSD), other anxiety-related disorders, and even substance use disorders [5, 6]. Many studies have examined the neural substrate of the observed post-retrieval amnesia through local manipulations in specific brain areas (e.g., [4, 7], while others have relied on the use of systemic pharmacological manipulations following memory reactivation (e.g., [8-11]. Whereas local administration obviously provides higher spatial accuracy, disadvantages may include unwanted effects of protein synthesis inhibitors, such as cell death at the site of injection, and the need for specific assumptions regarding the key region of interest [12]. An obvious advantage of systemic pharmacological manipulations, on the other hand, is the higher translatability of findings to clinical applications. A prime example is the use of propranolol for postretrieval attenuation of fear memories, first shown in fear-conditioned rodents [8], and later also in fearconditioned humans [13] (but see [14]) and spider phobics [15]. Propranolol is a centrally acting betaadrenergic antagonist and has repeatedly been shown to be effective for the induction of amnesia upon reactivation of the targeted memory. Although safe and apparently successful, propranolol seems to be the odd one out in light of the widely supported (but sometimes contested [16]) mechanism underlying the observed amnesia, i.e., reconsolidation interference. The reconsolidation hypothesis states that a consolidated memory can re-enter a labile phase through reactivation, which then requires protein synthesis (during reconsolidation) in order to preserve the original memory [4]. Given the proposed prerequisite of protein synthesis, the most obvious way to interfere with such reconsolidation is through administration of protein synthesis inhibitors, which have been used often and with success, although their profile is much more toxic than that of propranolol (which is assumed to have indirect effects on protein synthesis [5]). Commonly used protein synthesis inhibitors in this field of research include anisomycin, cycloheximide, and rapamycin. Systemic anisomycin, for instance, has been successfully used for induction of post-retrieval amnesia in several behavioral procedures (e.g., context conditioning, conditioned place preference) in numerous rodent studies $([17-22]$ are only a few examples).

A few years ago, we set out to optimize a protocol to investigate post-retrieval amnesia in rat fear conditioning in our laboratory. Auditory fear conditioning is a germane tool to study mechanisms central to anxietyrelated disorders, such as PTSD and phobias, and was therefore the focus of our effort. The literature seems to suggest that drug-induced post-retrieval amnesia is relatively easy to obtain, considering the many successful studies with rats and mice, using a plethora of different pharmacological agents $[6,23]$. Furthermore, to our knowledge, there are no published failures to find such a drug-induced amnestic effect with rodent auditory fear conditioning. Several studies do indicate that the effect is not, or less easily, found with old or strong memories (e.g., [24] (auditory fear), [25] (inhibitory avoidance), [22, 26] (contextual fear)), but all these papers do find evidence for amnesia under "standard conditions," i.e., recent fear memories that are reactivated through a typical protocol (e.g., one unreinforced presentation of the conditioned stimulus), after which administration of the drug results in a considerable deficit in memory expression, usually tested 1 day later [27].

Of note, published studies using systemic or intraamygdala injection of propranolol, anisomycin, or cycloheximide typically report (very) large effects (e.g., [4, 810, 28, 29]. Considering these effect sizes, the studies presented here are well-powered to detect differences between drug-treated and control groups. Published effect sizes with rapamycin are considerably smaller (e.g., $[11,30,31]$, but this protein synthesis inhibitor has the benefit of typically being administered systemically (see also, e.g., [18, 32, 33]). Moreover, rapamycin and analogs are approved for use in transplant and cancer patients, making it a worthwhile candidate to explore in view of future clinical applications [34].

To summarize, we conducted a series of sufficiently powered auditory fear conditioning experiments in adult male rats (see the "Power calculations" section for details), in which we aimed to induce amnesia by systemically administering one of four drugs (propranolol, rapamycin, anisomycin, or cycloheximide) after retrieval of the tone fear memory. Experimental parameters (e.g., shock intensity, testing conditions) were varied slightly in between experiments in order to optimize our 
chances of finding the effect and included an exact replication of Debiec and LeDoux [8]. In addition, we carried out control experiments and analyses to confirm that the drugs were biologically active at the applied dose and administration route. More specifically, as a positive control, we investigated the effect of cycloheximide on the consolidation of fear memories, by administering the drug immediately after training, rather than after reactivation, in line with published studies which again report large effect sizes [35-37]. In a subset of animals, we also evaluated the effect of cycloheximide on the consolidation of an extinction memory.

\section{Results}

No evidence for drug-induced post-retrieval amnesia ("reconsolidation interference")

In experiments 1-4, we aimed to induce postretrieval amnesia using systemic propranolol (Fig. 1), in experiments 5-6 with rapamycin (Fig. 2), and in experiment 7 with anisomycin or cycloheximide (Fig. 3). Relevant statistical analyses are reported in Table 1. In all experiments, drug-treated and control animals showed no significant differences in freezing during the reactivation CS, suggesting similar retrieval of the cued fear memory in each group. Freezing before the CS during both reactivation and test 1 sessions was very low in all experiments, indicative of tone fear memory retrieval that was unconfounded by contextual fear. Cued fear memory retention on test 1 was evaluated through freezing during the first 3 or 4 CSs. Against our expectations, there was no evidence for amnesia in the drug-treated animals in any of the experiments. Given the lack of any effects of propranolol, rapamycin, anisomycin, or cycloheximide, additional Bayesian analyses were carried out that collectively suggested substantial evidence for the absence of an amnestic effect in this series of experiments.

Further extinction, spontaneous recovery, renewal and/or reinstatement of memory expression was evaluated, as illustrated in Figs. 1, 2, and 3. No group differences were found, as to be expected given the lack of amnestic effects on test 1 .

\section{Evidence for drug-induced effects on freezing, body weight, and memory consolidation}

To further characterize the effects of the drugs at the applied dose and administration route in adult male Sprague-Dawley rats, several additional analyses and experiments were carried out. These do suggest that the drugs have detectable effects on freezing behavior, on body weight gain, and on consolidation of fear and extinction memories, as detailed below. All relevant statistical analyses are reported in Table 2.

\section{Acute drug effects on freezing behavior}

In experiment 4, propranolol was administered prior to memory reactivation, allowing us to evaluate its effects on freezing during the CS (Fig. 1i). Freezing in the Prop group was lower than in the control condition, but the effect was too small to be statistically significant with a sample size of 8 per group. In a recent study, we evaluated the effect of propranolol injection $20 \mathrm{~min}$ before a session with 12 CS presentations in 29 Prop and 26 Sal rats and did find significantly lower freezing in the Prop group (Luyten et al., in preparation). In addition, we found effects of anisomycin and cycloheximide during the short-term memory test $4 \mathrm{~h}$ after injection. The analyses are shown in Table 2 and expounded in Additional file $1[9,11,30,31,38-40]$.

\section{Long-term effects of rapamycin, anisomycin, and cycloheximide on body weight}

Interference with protein synthesis on a systemic level has certain toxic effects (see also Additional file 1), and although not lethal at the applied dose, effects on body weight were anticipated. Indeed, when comparing the increase in body weight from the last measurement before until the last measurement after injection, animals that had received rapamycin (Fig. 2e), anisomycin, or cycloheximide (Fig. 3c) gained significantly less weight than control animals.

\section{Effects of cycloheximide on consolidation of fear and extinction memories}

In experiment 8 , we assessed the effects of cycloheximide on consolidation rather than reconsolidation. We hypothesized that injection of cycloheximide after fear acquisition would interfere with memory consolidation, resulting in decreased freezing during the first 3 CSs on test 1 (Fig. 3e). To our surprise, we found the opposite effect, with more freezing in the cycloheximide rats. It is unlikely that this was a nonspecific effect of cycloheximide on freezing, given that no such increases were observed during the period preceding the first test $1 \mathrm{CS}$ in experiment 8 , nor on test 1 in experiment 7 (which took place $24 \mathrm{~h}$ after injection). A subset of rats was further tested in experiment 8 to assess the effects of cycloheximide on extinction memory consolidation (Fig. 3g). During extinction (full test 1 session), both subgroups were equivalent and extinguished to the same degree, after which they received an injection with cycloheximide or vehicle. Our hypothesis that cycloheximide would interfere with consolidation of the extinction memory and thus result in more freezing on test 2 was confirmed and particularly evident on the first trial of this session, where vehicle animals showed good 


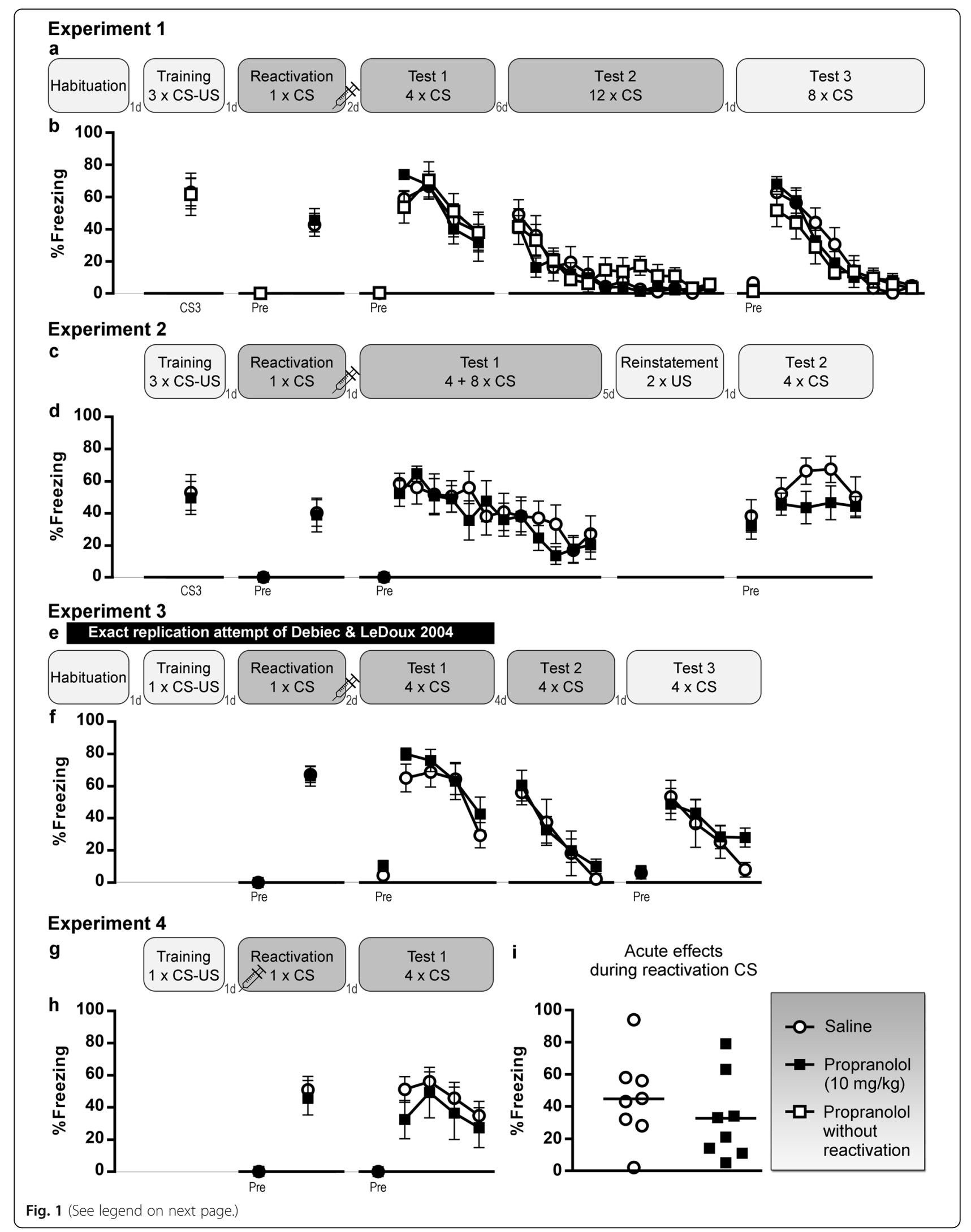


(See figure on previous page.)

Fig. 1 Propranolol (10 mg/kg) experiments. a, b Experiment 1, $n=8$ per group. c, d Experiment $2, n=8$ per group. e, $\mathbf{f}$ Experiment $3, n=6$ saline rats and $n=8$ propranolol rats. $\mathbf{g}$, $\mathbf{h}$ Experiment $4, n=7$ saline rats and $n=5$ propranolol rats. Percentage freezing during each tone (mean and SEM) is shown. "Pre" is contextual freezing before the first tone presentation of the session. $\mathbf{i}$ Acute effects of propranolol in experiment 4, in which the drug was administered immediately before rather than after reactivation, $n=8$ per group. Individual data and group means are shown. Light gray box indicates that a session takes place in context A, dark gray is context B. CS, conditioned stimulus; US, unconditioned stimulus; d, day(s)

\section{Experiment 5}

a
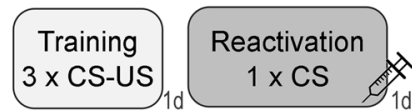

Test 1 $4+8 \times \mathrm{CS}$

Test 2

$12 \times \mathrm{CS}$
Test 3

$4 \times \mathrm{CS}$

b
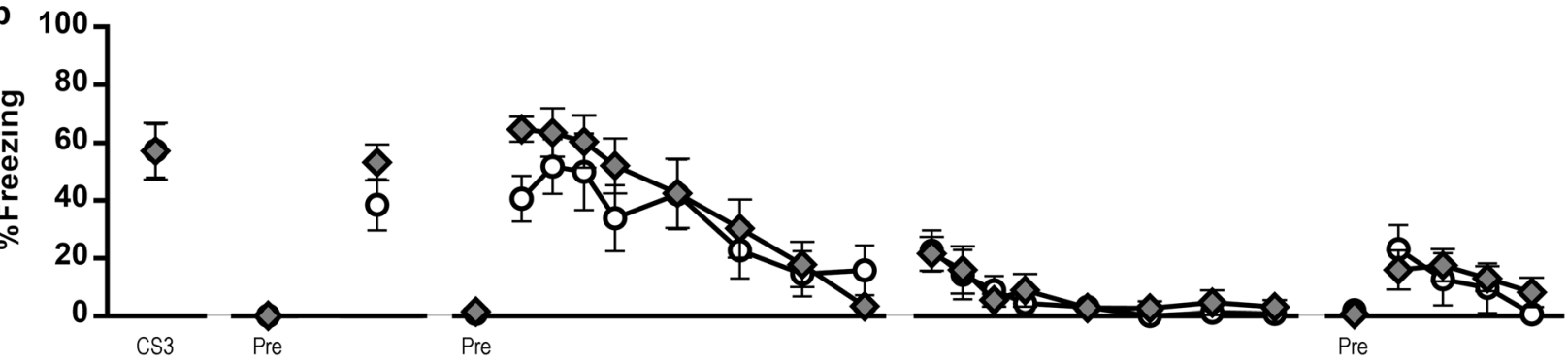

\section{Experiment 6}

c
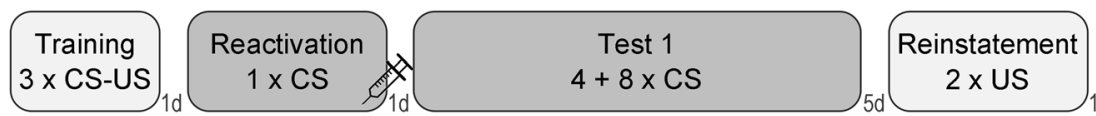

Test 2
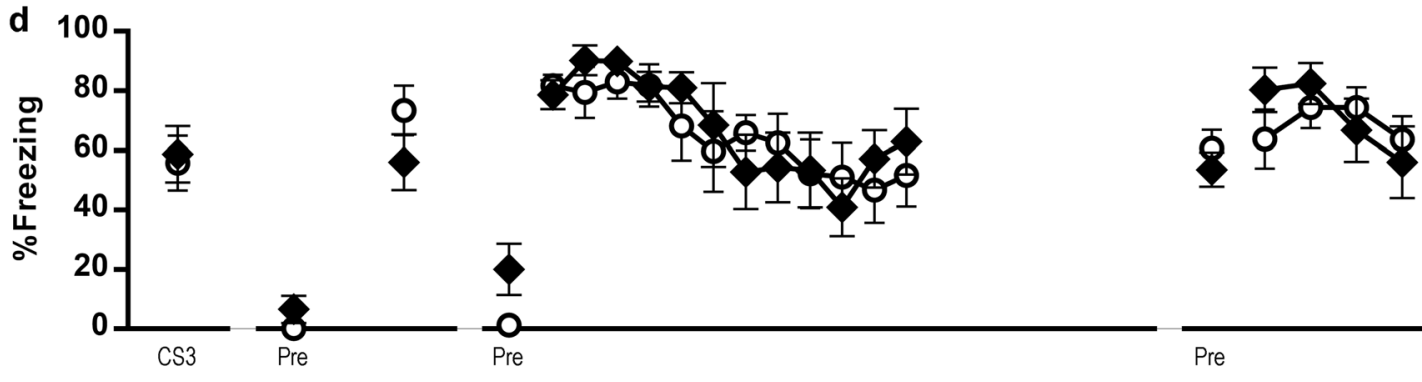

\section{Experiments $5 \& 6$}
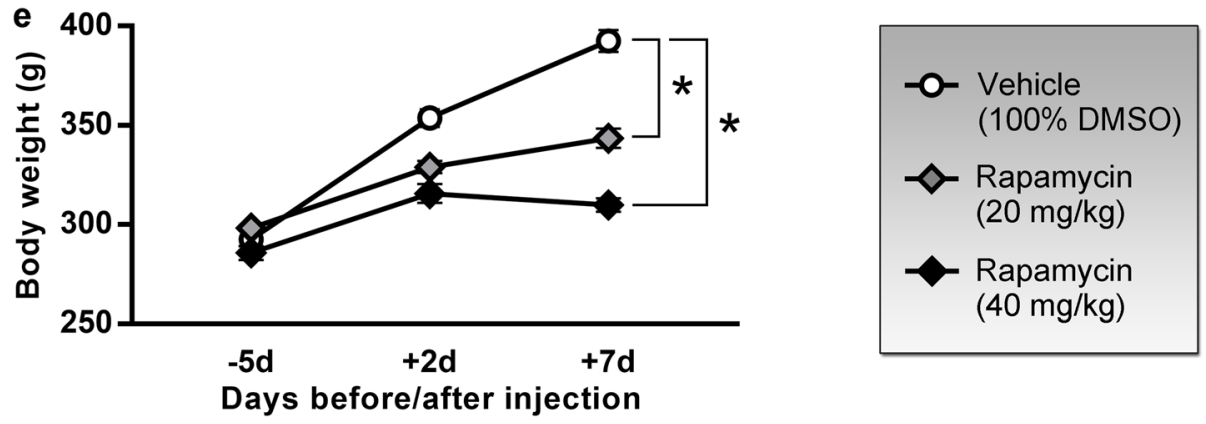

Fig. 2 Rapamycin (20-40 mg/kg) experiments. a, b Experiment 5 (20 mg/kg), $n=8$ per group. c, d Experiment 6 ( $40 \mathrm{mg} / \mathrm{kg}), n=8$ per group Percentage freezing during each tone (mean and SEM) is shown, except for tests 1 and 2 of experiment 5, where freezing during CS5-7-9-11 was not measured. "Pre" is contextual freezing before the first tone presentation of the session. e Effects on body weight (mean and SEM) in both experiments, $n=16$ vehicle (100\% DMSO) rats, $n=8$ rapamycin $(20 \mathrm{mg} / \mathrm{kg})$ rats, and $n=8$ rapamycin $(40 \mathrm{mg} / \mathrm{kg})$ rats. Light gray box indicates that a session takes place in context A, dark gray is context B. CS, conditioned stimulus; US, unconditioned stimulus; DMSO, dimethyl sulfoxide; d, day $(s)$, ${ }^{*}$ significant group differences $(p<.0001)$ 


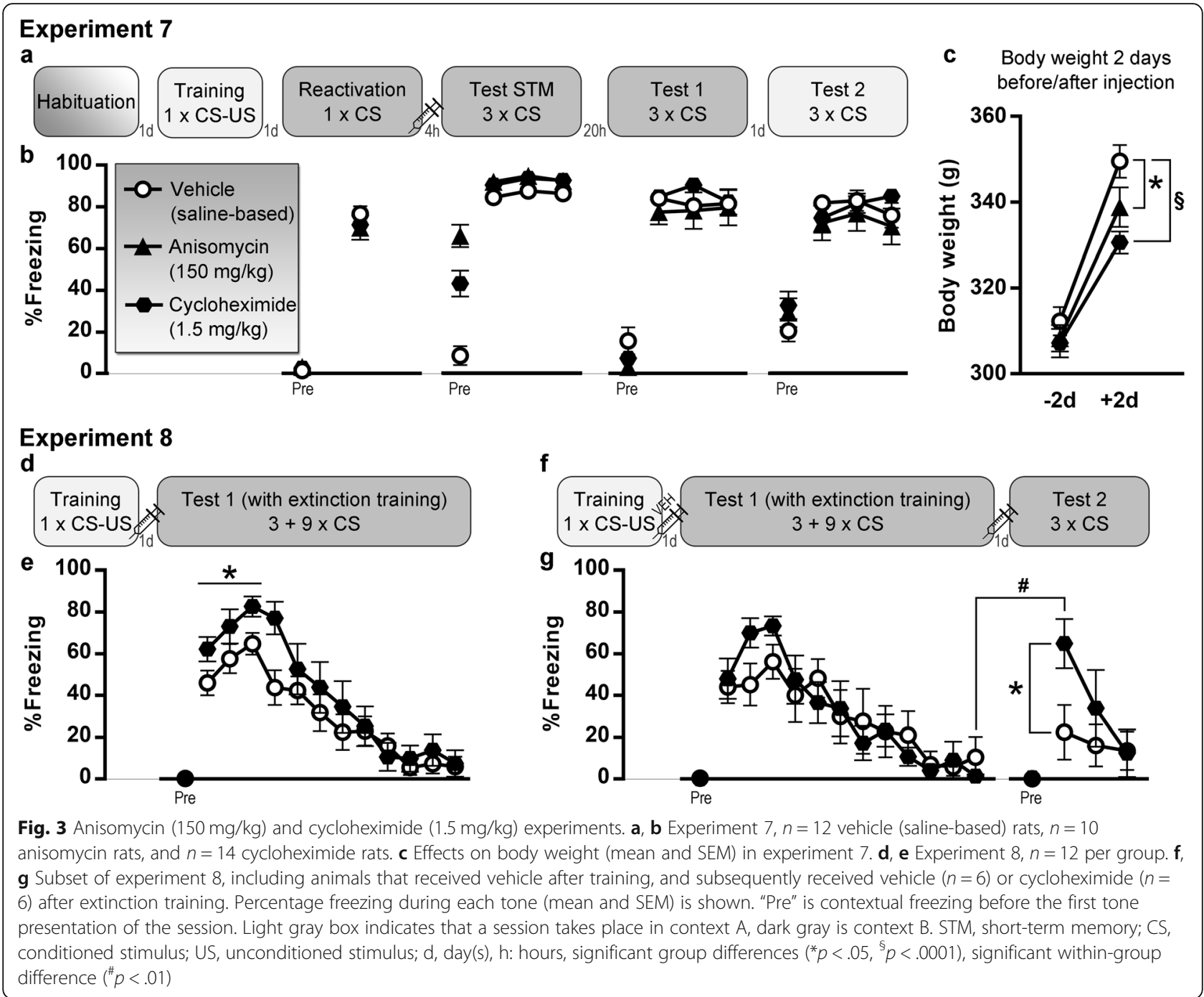

retention of the extinction memory, whereas cycloheximide animals did not.

\section{Discussion}

The aim of this series of experiments was to establish a protocol that could be used to probe the mechanisms of post-retrieval amnesia. We thus attempted to conceptually and exactly replicate prior published studies in which administration of propranolol, rapamycin, anisomycin, or cycloheximide upon auditory fear memory retrieval resulted in a significant attenuation of the fear response during subsequent tests (i.e., drug-induced post-retrieval amnesia). We adhered to universal behavioral procedures and pharmacological agents, including a direct replication attempt of [8], using sample sizes that were expected to yield sufficient power, in light of the current literature (e.g., $[4,8,33,41])$, which contains an abundance of studies that found post-retrieval amnesia, often with large effect sizes, and hardly any failures to replicate under standard training and reactivation conditions (one exception is Pitman et al. whose graph suggested no amnestic effect of propranolol but did not report any formal statistical analyses supporting this failure [42]). Therefore, we anticipated to readily reproduce the effect in our laboratory. Against our expectations, we did not find any evidence for an amnestic effect, and Bayesian analyses even indicated substantial evidence for the absence of an effect (Table 1). Inasmuch as we administered all drugs systemically and confined this endeavor to auditory fear memories, our conclusions cannot surpass these procedural choices. Nevertheless, in a recent study, we also described repeated failures to find post-retrieval amnesia in contextual fear conditioning studies with Wistar and Sprague-Dawley rats, using either propranolol or midazolam injections [43], suggesting that these reproducibility problems may extend to other fear conditioning procedures and pharmacological agents as well. 
Table 1 No evidence in favor of a post-retrieval amnestic effect

\begin{tabular}{|c|c|c|c|c|c|c|c|c|c|c|c|c|}
\hline Experiment & Figure & $\begin{array}{l}\text { Drug } \\
\text { condition }\end{array}$ & $n$ & $\begin{array}{l}\text { Control } \\
\text { condition }\end{array}$ & $n$ & $\begin{array}{l}\text { Reactivation } \\
\text { CS (two- } \\
\text { sided } t \text { test) }\end{array}$ & $\begin{array}{l}\text { Retention } \\
\text { test }\end{array}$ & $\begin{array}{l}\text { Retention } \\
\text { test (one- } \\
\text { sided } t \\
\text { test, } \\
\text { drug }< \\
\text { control) }\end{array}$ & $\begin{array}{l}\text { Retention } \\
\text { test (RM } \\
\text { ANOVA, } \\
\text { Trial by } \\
\text { group } \\
\text { effect) }\end{array}$ & $\begin{array}{l}\text { Retention } \\
\text { test } \\
\text { (Bayesian } \\
\text { one-sided } \\
t \text { test, } \\
\text { drug < } \\
\text { control) } \\
\end{array}$ & $\begin{array}{l}\text { Retention } \\
\text { test } \\
\text { (Bayesian } \\
\text { evidence } \\
\text { against } \\
\text { drug < } \\
\text { control) } \\
\end{array}$ & $\begin{array}{l}\text { Retention } \\
\text { test } \\
\text { (Bayesian } \\
\text { one-sided } \\
\text { meta-analysis) }\end{array}$ \\
\hline $\begin{array}{l}\text { Experiment } \\
1\end{array}$ & $1 b$ & Prop & 8 & Sal & 8 & $\begin{array}{l}t(14)=0.29 \\
p=.78\end{array}$ & $\begin{array}{l}\text { Test } 1 \\
\text { (4 CSs) }\end{array}$ & $\begin{array}{l}t(14)=0.12 \\
p=.55\end{array}$ & $\begin{array}{l}F(3,42) \\
=0.96, p=.42\end{array}$ & $\mathrm{BF}_{01}=2.52$ & Anecdotal & \multirow{9}{*}{$\begin{array}{l}\mathrm{BF}_{01}=9.93 \\
\text { suggesting } \\
\text { substantial } \\
\text { evidence for } \\
\text { the absence } \\
\text { of an amnestic } \\
\text { effect }\end{array}$} \\
\hline $\begin{array}{l}\text { Experiment } \\
1\end{array}$ & $1 b$ & Prop & 8 & $\begin{array}{l}\text { Prop } \\
\text { NoReact }\end{array}$ & 8 & NA & $\begin{array}{l}\text { Test } 1 \\
(4 \text { CSs) }\end{array}$ & $\begin{array}{l}\mathrm{t}(14)=0.01 \\
p=.50\end{array}$ & $\begin{array}{l}F(3,42) \\
=2.02, p=.13\end{array}$ & $\mathrm{BF}_{01}=2.35$ & Anecdotal & \\
\hline $\begin{array}{l}\text { Experiment } \\
2\end{array}$ & $1 d$ & Prop & 8 & Sal & 8 & $\begin{array}{l}\mathrm{t}(14)=-0.09 \\
p=.93\end{array}$ & $\begin{array}{l}\text { Test } 1 \\
\text { (4 CSs) }\end{array}$ & $\begin{array}{l}\mathrm{t}(14)=0.01 \\
p=.50\end{array}$ & $\begin{array}{l}F(3,42) \\
=0.56, p=.64\end{array}$ & $\mathrm{BF}_{01}=2.35$ & Anecdotal & \\
\hline $\begin{array}{l}\text { Experiment } \\
3\end{array}$ & if & Prop & 8 & Sal & 6 & $\begin{array}{l}\mathrm{t}(12)=-0.13 \\
p=.90\end{array}$ & $\begin{array}{l}\text { Test } 1 \\
(4 \mathrm{CSs})\end{array}$ & $\begin{array}{l}\mathrm{t}(12)=0.84 \\
p=.79\end{array}$ & $\begin{array}{l}F(3,36) \\
=0.69, p=.57\end{array}$ & $\mathrm{BF}_{01}=3.45$ & Substantial & \\
\hline $\begin{array}{l}\text { Experiment } \\
4\end{array}$ & $1 \mathrm{~h}$ & Prop & 5 & Sal & 7 & $\begin{array}{l}\mathrm{t}(10)=-.0 .37 \\
p=.72\end{array}$ & $\begin{array}{l}\text { Test } 1 \\
(4 \text { CSs) }\end{array}$ & $\begin{array}{l}\mathrm{t}(4.52)= \\
-0.77, p=.24\end{array}$ & $\begin{array}{l}\mathrm{F}(3,30) \\
=0.24, p=.87\end{array}$ & $\mathrm{BF}_{01}=1.09$ & Anecdotal & \\
\hline $\begin{array}{l}\text { Experiment } \\
5\end{array}$ & $2 b$ & Rap 20 & 8 & Veh & 8 & $\begin{array}{l}\mathrm{t}(14)=1.34 \\
p=.20\end{array}$ & $\begin{array}{l}\text { Test } 1 \\
\text { (4 CSs) }\end{array}$ & $\begin{array}{l}\mathrm{t}(14)=1.43 \\
p=.91\end{array}$ & $\begin{array}{l}F(3,42) \\
=0.59, p=0.63\end{array}$ & $\mathrm{BF}_{01}=4.59$ & Substantial & \\
\hline $\begin{array}{l}\text { Experiment } \\
6\end{array}$ & $2 d$ & Rap 40 & 8 & Veh & 8 & $\begin{array}{l}\mathrm{t}(14)=-1.38 \\
p=.19\end{array}$ & $\begin{array}{l}\text { Test } 1 \\
\text { (4 CSs) }\end{array}$ & $\begin{array}{l}\mathrm{t}(14)=0.51 \\
p=.69\end{array}$ & $\begin{array}{l}F(3,42)=1.83, \\
p=.16\end{array}$ & $\mathrm{BF}_{01}=3.13$ & Substantial & \\
\hline $\begin{array}{l}\text { Experiment } \\
7\end{array}$ & $3 b$ & Ani & 10 & Veh & 12 & $\begin{array}{l}\mathrm{t}(20)=-0.97 \\
p=.34\end{array}$ & $\begin{array}{l}\text { Test } 2 \\
\text { (3 CSs) }\end{array}$ & $\begin{array}{l}t(10.08)= \\
-0.49, p=.32\end{array}$ & $\begin{array}{l}F(2,40)=0.33 \\
p=.72\end{array}$ & $\mathrm{BF}_{01}=1.75$ & Anecdotal & \\
\hline $\begin{array}{l}\text { Experiment } \\
7\end{array}$ & $3 b$ & Cyclo & 14 & Veh & 12 & $\begin{array}{l}\mathrm{t}(24)=-0.91 \\
p=.37\end{array}$ & $\begin{array}{l}\text { Test } 2 \\
\text { (3 CSs) }\end{array}$ & $\begin{array}{l}\mathrm{t}(24)=1.04 \\
p=.84\end{array}$ & $\begin{array}{l}\mathrm{F}(2,80)=1.39, \\
p=.26\end{array}$ & $\mathrm{BF}_{01}=4.83$ & Substantial & \\
\hline
\end{tabular}

Statistical evaluation of post-retrieval amnesia with systemic administration of propranolol, rapamycin, anisomycin, or cycloheximide provides no evidence in favor of an amnestic effect. Note that $\mathrm{BF}_{01}$ quantifies the obtained evidence in favor of the null hypothesis (i.e., absence of an amnestic effect) relative to the alternative hypothesis (i.e., presence of an amnestic effect). For the Bayesian meta-analysis, the comparison of Prop versus Prop NoReact in experiment 1 was not included as this was a comparison with an additional control condition. Ani anisomycin (150 mg/kg), Cyclo cycloheximide (1.5 mg/kg), Prop propranolol (10 mg/kg), Rap 20 rapamycin $(20 \mathrm{mg} / \mathrm{kg})$, Rap 40 rapamycin $(40 \mathrm{mg} / \mathrm{kg})$, Sal saline, Veh vehicle

The lack of amnestic effects in the current paper may have several causes [23]. Drug-induced post-retrieval amnesia entails two crucial elements: a suitable drug and appropriate retrieval. First, it is possible that the pharmacological agents that we administered were all ineffective in interfering with memory retention. Second, the various behavioral procedures that we used might not have resulted in actual memory reactivation, understood as a destabilization of the memory trace which is required in order to interfere with it, as proposed by the reconsolidation blockade hypothesis [4]. Instead of having this intended effect, our reactivation session may have led to mere retrieval, without destabilization [44]. We cannot be absolutely sure if one or both factors account for our results, and there are, of course, countless parametric variations that we did not try. Nevertheless, below, we will argue why such "easy" explanations for our data and conclusions are debatable.

First, in order to evaluate whether the drugs had any biological effects at the applied dose and administration route, we performed several additional tests and analyses (Table 2). We observed acute effects of propranolol, anisomycin and cycloheximide on freezing behavior. The effects of both protein synthesis inhibitors most likely reflect transient and non-specific changes in general mobility of the animals, in line with signs of sickness that appear shortly after injection of such drugs (Additional file $1,[9,39]$ ). Decreased freezing following propranolol administration presumably does represent a genuine reduction in fear expression [45] and is in line with its beta-blocking effects which produce an attenuation of heart rate and blood pressure [46]. In addition to these effects on freezing behavior, we found that the protein synthesis inhibitors (i.e., rapamycin, anisomycin, and cycloheximide) had long-lasting effects on body weight. After a single injection, animals in the drug conditions gained significantly less weight than vehicle controls over a period of several days, in line with prior studies [47, 48]. Last but not least, we investigated whether we were able to interfere with consolidation, rather than reconsolidation (experiment 8). We used cycloheximide in this study because of its lower toxicity compared to anisomycin (Additional file 1), the anticipated larger effects in comparison with rapamycin, and the documented ineffectiveness of propranolol to interfere with consolidation of auditory fear [8]. We first examined the effect on consolidation of fear memory, and found an unexpected but significant effect in the opposite direction, i.e., better retention (indexed as higher freezing) at the start of the test session in drug-treated animals. Importantly, when we next investigated the effect of cycloheximide on consolidation of the extinction 
Table 2 The applied drugs do have other detectable physiological effects

\begin{tabular}{|c|c|c|c|c|c|c|c|c|c|}
\hline & Experiment & Figure & $\begin{array}{l}\text { Drug } \\
\text { condition }\end{array}$ & $n$ & $\begin{array}{l}\text { Control } \\
\text { condition }\end{array}$ & $n$ & $\begin{array}{l}\text { Evaluated } \\
\text { drug effect }\end{array}$ & $\begin{array}{l}\text { Statistical } \\
\text { analysis }\end{array}$ & Result \\
\hline \multirow[t]{6}{*}{$\begin{array}{l}\text { Short-term } \\
\text { effects on } \\
\text { freezing } \\
\text { behavior }\end{array}$} & Experiment 4 & $1 \mathrm{i}$ & Prop & 8 & Sal & 8 & $\begin{array}{l}\text { Acute effect on } \\
\text { freezing during } \\
\text { tone CS (1 CS } \\
\text { presentation) }\end{array}$ & $\begin{array}{l}\text { Two-sided } t \\
\text { test (reactivation CS) }\end{array}$ & $\mathrm{t}(14)=-0.93, p=.37, d=0.50$ \\
\hline & $\begin{array}{l}\text { Luyten et al. } \\
\text { in preparation }\end{array}$ & / & Prop & 29 & Sal & 26 & $\begin{array}{l}\text { Acute effect on } \\
\text { freezing during } \\
\text { tone CS ( } 12 \text { CS } \\
\text { presentations) }\end{array}$ & $\begin{array}{l}\text { Two-sided } t \text { test } \\
\text { (average of } 12 \text { CSs) }\end{array}$ & $\mathrm{t}(53)=-2.36, \boldsymbol{p}<.05, d=0.65$ \\
\hline & Experiment 7 & $3 a$ & Ani & 10 & Veh & 12 & $\begin{array}{l}\text { Short-term }(4 \mathrm{~h}) \\
\text { effect on freezing } \\
\text { before tone CS }\end{array}$ & $\begin{array}{l}\text { Two-sided } t \text { test } \\
\text { (STM test PreCS)* }^{*}\end{array}$ & $\mathrm{t}(20)=8.14, \boldsymbol{p}<. \mathbf{0 0 0 1}, d=3.65$ \\
\hline & Experiment 7 & $3 a$ & Ani & 10 & Veh & 12 & $\begin{array}{l}\text { Short-term ( } 4 \mathrm{~h} \text { ) } \\
\text { effect on freezing } \\
\text { during tone CS ( } 3 \\
\text { CS presentations) }\end{array}$ & $\begin{array}{l}\text { Two-sided Welch's } t \\
\text { test (STM test average } \\
\text { of CS1-3)* }\end{array}$ & $\mathrm{t}(12.76)=4.20, \boldsymbol{p}<. \mathbf{0 1}, d=1.74$ \\
\hline & Experiment 7 & $3 a$ & Cyclo & 14 & Veh & 12 & $\begin{array}{l}\text { Short-term }(4 \mathrm{~h}) \\
\text { effect on freezing } \\
\text { before tone CS }\end{array}$ & $\begin{array}{l}\text { Two-sided } t \text { test } \\
\text { (STM test PreCS)* }^{*}\end{array}$ & $\mathrm{t}(24)=4.36, \boldsymbol{p}<. \mathbf{0 0 1}, d=1.79$ \\
\hline & Experiment 7 & $3 a$ & Cyclo & 14 & Veh & 12 & $\begin{array}{l}\text { Short-term ( } 4 \mathrm{~h} \text { ) } \\
\text { effect on freezing } \\
\text { during tone CS ( } 3 \\
\text { CS presentations) }\end{array}$ & $\begin{array}{l}\text { Two-sided } t \text { test } \\
(\text { STM test average } \\
\text { of } \mathrm{CS} 1-3)^{*}\end{array}$ & $\mathrm{t}(24)=3.46, \boldsymbol{p}<. \mathbf{0 1}, d=1.42$ \\
\hline \multirow[t]{4}{*}{$\begin{array}{l}\text { Long-term } \\
\text { effects on } \\
\text { body weight }\end{array}$} & Experiment 5 & $2 e$ & Rap 20 & 8 & Veh & 8 & $\begin{array}{l}\text { Effect on body } \\
\text { weight ( } 7 \mathrm{~d} \text { after } \\
\text { injection) }\end{array}$ & $\begin{array}{l}\text { Two-sided } t \text { test } \\
\text { (increase from }-5 d \\
\text { to }+7 d \text { ) }\end{array}$ & $\begin{array}{l}\mathrm{t}(14)=-10.35, \boldsymbol{p}<. \mathbf{0 0 0 1} \\
d=5.53\end{array}$ \\
\hline & Experiment 6 & $2 e$ & Rap 40 & 8 & Veh & 8 & $\begin{array}{l}\text { Effect on body } \\
\text { weight ( } 7 d \text { after } \\
\text { injection) }\end{array}$ & $\begin{array}{l}\text { Two-sided } t \text { test } \\
\text { (increase from }-5 \mathrm{~d} \\
\text { to }+7 \mathrm{~d} \text { ) }\end{array}$ & $\begin{array}{l}\mathrm{t}(14)=-7.37, \boldsymbol{p}<. \mathbf{0 0 0 1} \\
d=3.94\end{array}$ \\
\hline & Experiment 7 & $3 c$ & Ani & 10 & Veh & 12 & $\begin{array}{l}\text { Effect on body } \\
\text { weight ( } 2 d \text { after } \\
\text { injection) }\end{array}$ & $\begin{array}{l}\text { Two-sided } t \text { test } \\
\text { (increase from }-2 \mathrm{~d} \\
\text { to }+2 \mathrm{~d} \text { ) }\end{array}$ & $\mathrm{t}(20)=-2.55, \boldsymbol{p}<.05, d=1.14$ \\
\hline & Experiment 7 & $3 c$ & Cyclo & 14 & Veh & 12 & $\begin{array}{l}\text { Effect on body } \\
\text { weight ( } 2 \mathrm{~d} \text { after } \\
\text { injection) }\end{array}$ & $\begin{array}{l}\text { Two-sided } t \text { test } \\
\text { (increase from }-2 \mathrm{~d} \\
\text { to }+2 \mathrm{~d} \text { ) }\end{array}$ & $\begin{array}{l}\mathrm{t}(24)=-5.44, \boldsymbol{p}<. \mathbf{0 0 0 1} \\
d=2.23\end{array}$ \\
\hline \multirow[t]{3}{*}{$\begin{array}{l}\text { Effects on } \\
\text { memory } \\
\text { consolidation }\end{array}$} & Experiment 8 & $3 e$ & Cyclo & 12 & Veh & 12 & $\begin{array}{l}\text { Effect on } \\
\text { consolidation } \\
\text { of tone fear } \\
\text { memory (1d } \\
\text { after injection) }\end{array}$ & $\begin{array}{l}\text { Repeated-measures } \\
\text { ANOVA (test 1, } \\
\text { CS1-2-3)* }\end{array}$ & $\begin{array}{l}\text { Group effect }(F(1,22)=5.53 \\
\left.p<.05, \eta_{p}^{2}=.20\right), \text { Trial effect } \\
(F(2,44)=8.79, p<.001 \\
\left.\eta_{p}^{2}=.29\right), \text { no interaction }\end{array}$ \\
\hline & Experiment 8 & $3 g$ & Cyclo & 6 & Veh & 6 & $\begin{array}{l}\text { Effect on } \\
\text { consolidation of } \\
\text { extinction memory } \\
\text { (1d after injection) }\end{array}$ & $\begin{array}{l}\text { Repeated-measures } \\
\text { ANOVA (test 2, } \\
\text { CS1-2-3)* }\end{array}$ & $\begin{array}{l}\text { Trend for group by trial } \\
\text { interaction }(F(2,20)=3.38, \\
\left.\boldsymbol{p}=.05, \eta_{p}^{2}=.25\right) \text {, Trial effect } \\
\left(F(2,20)=6.71, p<.01, \eta_{p}^{2}=.40\right) \text {, } \\
\text { no Group effect }\end{array}$ \\
\hline & Experiment 8 & $3 g$ & Cyclo & 6 & Veh & 6 & $\begin{array}{l}\text { Effect on } \\
\text { consolidation of } \\
\text { extinction memory } \\
\text { (1d after injection) }\end{array}$ & $\begin{array}{l}\text { Repeated-measures } \\
\text { ANOVA (test 1, last } \\
\text { CS vs test 2, first CS) }\end{array}$ & $\begin{array}{l}\text { Group by test interaction } \\
(F(1,10)=5.64, \boldsymbol{p}<.05 \\
\left.\eta_{p}^{2}=.36\right) \text {, Test effect }(F(1,10) \\
\left.=12.17, p<.01, \eta_{p}^{2}=.55\right) \\
\text { no Group effect }\end{array}$ \\
\hline
\end{tabular}

Statistical evaluation of other effects of propranolol, rapamycin, anisomycin, or cycloheximide suggests that the drugs (same dose and route as in Table 1) do have detectable physiological effects. Ani anisomycin (150 mg/kg), Cyclo cycloheximide (1.5 mg/kg), Prop propranolol (10 mg/kg), Rap 20 rapamycin (20 mg/kg), Rap 40 rapamycin $(40 \mathrm{mg} / \mathrm{kg})$, Sal saline, Veh vehicle; * preregistered analysis

memory, we did indeed find evidence for amnesia. Animals that had received the protein synthesis inhibitor showed worse retention than controls, indicative of interference with the consolidation of fear extinction. All in all, we found clear short- and long-term behavioral and physiological effects of the pharmacological agents that we used, along with effects on consolidation, arguing against the possibility that our drugs were generally ineffective using the administration route and dose that we applied in experiments 1-7.

Second, as mentioned above, we cannot exclude that, in experiments 1-7, we failed to induce the 
destabilization that is thought to be required in order for the retrieved fear memory to undergo changes that can result in amnesia. Although our memories were presumably not too old or too strong (two conditions that may hamper post-retrieval amnesia [22, 24]), and our animals clearly retrieved the fear memory during the reactivation session (moderate to high freezing upon presentation of the conditioned tone), we cannot be sure that the memory destabilized. Prior research supports that such destabilization only occurs when the reactivation session involves an appropriate degree of prediction error, which is a function of the extent to which the contingencies at the time of retrieval match the contingencies at the time of memory acquisition [49]. We can assume that, in our experiments, the mismatch between the unreinforced reactivation tone and the preceding acquisition session (100\% reinforced tones) was large enough to create the amount of prediction error that appears to be required for memory destabilization and subsequent interference with its restabilization [50, 51]. Moreover, given the similarity of our protocols and the observed freezing levels during the reactivation session (see Additional file 2) $[4,8,23,24,28,52-55]$ with those of published reports, it is unlikely that there was no such mismatch.

A noteworthy difference between previous publications and our work is that the animals were obtained from a different supplier. Our rats were of the same strain, age, and sex as in many prior reports, but we cannot exclude that small genetic variations [56] or subtle differences in earlylife experiences [57] influenced susceptibility to druginduced post-retrieval amnesia. Laboratories that reliably find amnestic effects could examine this in more detail, by comparing post-retrieval amnesia in (different strains of) rodents from different suppliers, or by investigating the effects of genetic or environmental manipulations on the success of this intervention. If such small (epi)genetic variations turn out to be crucial, this observation has farreaching implications for the overall generalizability of drug-induced post-retrieval amnesia of fear memories. Our replication failures indeed suggest that obtaining amnestic effects depends on very subtle differences between experiments. This makes the current lack of published null findings even more unfortunate, because the field needs information about the conditions under which the effect is not found as much as the success stories, in order to identify these unknown conditions that may influence memory malleability.

As mentioned above, the conclusions of this paper are limited to systemic drug administration and cued fear memory, a deliberate choice in light of the direct relevance of such procedures to clinical applications, e.g., for traumatized patients [58]. It is absolutely possible that local drug infusion (e.g., in the amygdala, cf. $[4,28]$ ) would have permitted us to observe amnestic effects, given that intracerebral administration-albeit clinically less relevant for the time being-provides a temporal and spatial precision that cannot be achieved with systemic administration. In addition, it is possible that the cannulated rats that were tested in part of the prior literature behaved or even learned somewhat differently compared to our non-operated animals. Bear in mind however that the large majority of the studies that we present here rely on protocols that have been used often and successfully for the induction of post-retrieval amnesia using systemic administration in non-operated rats.

An additional caveat is that, even though our experiments with propranolol, anisomycin, and cycloheximide were well-powered in view of the effects reported in the literature, those effect sizes may be a gross overestimation of the true effect [59]. Even a true effect will occasionally lead to a non-significant finding, given the nature of the statistical analyses that are typically used to support the presence of the effect $(\alpha=.05)$. That being said, it is implausible that such statistical considerations may comprehensively account for the lack of amnesia that we observed here. We found not even a trend for amnesia and, moreover, Bayesian analyses suggested substantial evidence for the absence of such effect.

Finally, we note that attempts to pharmacologically induce post-retrieval amnesia in other aversive learning procedures, such as inhibitory avoidance or immediate shock conditioning after context pre-exposure, have met with varying degrees of success [23, 29, 60]. Our results also fit with the mixed findings in the human cued fear conditioning literature. Although several human fear conditioning studies have found propranolol-induced post-retrieval amnesia [13, 61], others reported failures to replicate this result [14, 46, 62]. Furthermore, our series of null findings in rodents aligns with personal communication from several researchers in the field and reports in unpublished dissertations (e.g., [63]) of failures to find drug-induced post-retrieval amnesia in rat or mouse fear conditioning under standard training and reactivation conditions. This striking contrast with most of the existing rodent literature suggests a reporting bias, although we cannot substantiate such claim with the current study alone. Moreover, we do not intend to question the veracity of this phenomenon as a whole. Rather, our data should be seen as an important warning against overly enthusiastic statements regarding the generalizability and clinical translatability of druginduced post-retrieval amnesia.

\section{Conclusions}

In contrast with most published studies, we did not find evidence for drug-induced post-retrieval amnesia in rats. 
We conclude that this effect may be considerably more constrained and less readily reproduced than what the current literature appears to suggest.

\section{Methods}

\section{Preregistration and data availability}

All experiments, including protocols, planned sample sizes, and analysis plans, were registered on the Open Science Framework (OSF) before the start of data collection (https://doi.org/10.17605/osf.io/j5dgx). All data can be found there too, as well as on Figshare (https://doi. org/10.6084/m9.figshare.c.5258129).

\section{Subjects}

One hundred sixty-four male Sprague-Dawley rats (270$300 \mathrm{~g}$ on arrival in the lab) (Janvier Labs, Le GenestSaint-Isle, France) were housed individually in plastic cages with bedding, food, and water ad libitum. Cage enrichment (Dura-Chew, Bio-Serv, Flemington, NJ, USA) was provided in experiments $2-5$. To monitor general wellbeing, animals were weighed at several points before, during, and/or after the experiments, but never on training (except for experiment 1), reactivation or test days, in order to disturb the behavioral sessions as little as possible. Body weight on the reactivation day (for calculation of the drug injection volume) was estimated as the most recent weight $+10 \mathrm{~g} /$ day. Experiments started 3-5 days after arrival in the lab. Animals were kept on a 12 $\mathrm{h} / 12 \mathrm{~h}$ day-night cycle, with experiments starting $1-2.5 \mathrm{~h}$ after the beginning of the light phase. Rats were brought from the housing facility to the testing room approximately 2 min before each behavioral session in their home cage, carried by the experimenter (experiment 1 ) or transported on a wheeled cart (all other experiments).

\section{Procedure}

Experimental designs, including the number of tones (conditioned stimulus, CS) and shocks (unconditioned stimulus, US) presented during each session, are shown in Fig. 1, 2, and 3. Specific details regarding tone and shock parameters and timing of the stimuli can be found in Table 3 and in the "Details regarding the timing of stimulus presentation" section. In all experiments, freezing was scored manually from videos by an experienced observer blinded to group allocation [64] and expressed as a percentage of the time under evaluation. Preregistered criteria for exclusion were less than $15 \%$ freezing during the reactivation CS in experiments 4 and 7, and exclusion from test 2 analyses in experiment 7 if freezing was less than $15 \%$ during the first 3 CSs of test 1.

\section{Equipment}

Four identical chambers (Contextual NIR Video Fear Conditioning System for Rats, Med Associates Inc., St. Albans, VT, USA) were equipped with specific contextual features for context A and context B. Built-in ventilation fans provided background noise $( \pm 67 \mathrm{~dB})$ in all chambers. Context A had a standard grid floor, a black triangular insert, was illuminated by infrared and white light $(50 \mathrm{~lx})$ and cleaned and scented with a pine odor cleaning product. Context B had a white plastic floor, a white plastic curved back wall insert, infrared light only, and was cleaned and scented with a different cleaning product.

\section{Experiments 1-7 Habituation}

In some experiments, animals were habituated to context $\mathrm{A}$ (experiments 1 and 3 ) or context $\mathrm{A}$ and context $\mathrm{B}$ (experiment 7) 1 day before training.

\section{Training}

To acquire a cued fear memory, rats received 1 or 3 tone-shock pairings in context A. Tones were $5000 \mathrm{~Hz}$, $75-80 \mathrm{~dB}$ for $20-30 \mathrm{~s}$, and co-terminated with the shocks $(0.7-1.5 \mathrm{~mA}, 0.5-1 \mathrm{~s}$, depending on the experiment, see details below). In experiments with 3 CS-US pairings, animals were matched into equivalent groups

Table 3 Parameters of conditioned (CS) and unconditioned stimuli (US) in experiments 1-8

\begin{tabular}{lllllll}
\hline Experiment number (experiment code on OSF) & CS (frequency, sound level, duration) & \multicolumn{2}{l}{$\begin{array}{l}\text { US (intensity, } \\
\text { duration) }\end{array}$} & CS-US pairings during training \\
\hline Experiment 1 (LLERC01) & $5000 \mathrm{~Hz}$ & $80 \mathrm{~dB}$ & $20 \mathrm{~s}$ & $0.7 \mathrm{~mA}$ & $0.5 \mathrm{~s}$ & 3 \\
Experiment 2 (LLERC08) & $5000 \mathrm{~Hz}$ & $80 \mathrm{~dB}$ & $20 \mathrm{~s}$ & $0.7 \mathrm{~mA}$ & $1.0 \mathrm{~s}$ & 3 \\
Experiment 3 (LLERC10) & $5000 \mathrm{~Hz}$ & $75 \mathrm{~dB}$ & $30 \mathrm{~s}$ & $1.0 \mathrm{~mA}$ & $1.0 \mathrm{~s}$ & 1 \\
Experiment 4 (LLERC11) & $5000 \mathrm{~Hz}$ & $75 \mathrm{~dB}$ & $30 \mathrm{~s}$ & $1.0 \mathrm{~mA}$ & $1.0 \mathrm{~s}$ & 1 \\
Experiment 5 (LLERC07) & $5000 \mathrm{~Hz}$ & $80 \mathrm{~dB}$ & $20 \mathrm{~s}$ & $0.7 \mathrm{~mA}$ & $0.5 \mathrm{~s}$ & 3 \\
Experiment 6 (LLERC09) & $5000 \mathrm{~Hz}$ & $80 \mathrm{~dB}$ & $20 \mathrm{~s}$ & $1.0 \mathrm{~mA}$ & $1.0 \mathrm{~s}$ & 3 \\
Experiment 7 (LLERC19) & $5000 \mathrm{~Hz}$ & $80 \mathrm{~dB}$ & $30 \mathrm{~s}$ & $1.5 \mathrm{~mA}$ & $1.0 \mathrm{~s}$ & 1 \\
Experiment 8 (LLERC22) & $5000 \mathrm{~Hz}$ & $80 \mathrm{~dB}$ & $30 \mathrm{~s}$ & $1.5 \mathrm{~mA}$ & $1.0 \mathrm{~s}$ & 1 \\
\hline
\end{tabular}


(block-randomization) based upon freezing during the third CS.

\section{Reactivation}

Twenty-four hours later, a single tone CS without shock was presented in context B with the aim of reactivating the cued fear memory and rendering it vulnerable to drug interference. Approximately 1-2 min after the end of the reactivation session, the drug or its control vehicle was injected systemically. In experiment 4 , the injection was given 3-6 min before (instead of after) reactivation. Having the propranolol on board during the reactivation phase may, theoretically, increase the opportunities to block reconsolidation already in the earliest stages after reactivation $[13,29,65]$. In experiment 7 , short-term memory was tested in context $\mathrm{B}, 4 \mathrm{~h}$ after reactivation (no amnestic effects were expected here).

\section{Tests}

One or two (in experiments 1 and 3) days later, retention of the tone fear memory was tested in context B (test 1), to evaluate the anticipated drug-induced postretrieval amnesia. This test consisted of 3 (in experiment 7) or 4 CS presentations. Note that in experiments 2, 5, and 6, more CSs were presented with the aim of inducing extinction. Nevertheless, the use of the first 3-4 CSs as an index of long-term fear memory retention was preregistered. Under the assumption that we were going to induce post-retrieval amnesia, most experiments featured additional tests to assess the robustness of the amnesia that we were expecting to see, including spontaneous recovery tests after (partial) extinction of the fear memory in experiments 1,3 , and 5 , renewal tests in context $\mathrm{A}$ in experiments $1,3,5$, and 7 , and reinstatement tests in experiments 2 and 6.

\section{Exact replications}

Experiment 3 (up to and including test 1) was an exact replication of Debiec amd LeDoux [8]. In addition, the behavioral procedure (up to test 1) of experiment 7 was an exact replication of a protocol used in Duvarci et al. [28] and Nader et al. [4] (details see Additional file 3) [4, $10,12,17,25,28,41,66-68]$. The route of drug administration did, however, differ between their studies (infusion into the basolateral amygdala) and ours, as we chose to use systemic injections throughout. All other experiments were conceptual replications of prior successful studies.

\section{Experiment 8}

Experiment 8 was designed to test drug effects on consolidation rather than reconsolidation. Therefore, on the first day, training of a cued fear memory with one toneshock pairing took place in context A, immediately followed by injection of cycloheximide or vehicle. One day later, retention of the cued fear memory (and possible effects of cycloheximide on its consolidation) was assessed during the first 3 CSs of test 1 in context B. This test session continued with further extinction of the cued fear memory. Immediately after this extinction training, rats that had received vehicle after training, now received cycloheximide or vehicle. One day later, retention of the extinction memory (and possible effects of cycloheximide on its consolidation) in this subset was assessed during test 2 in context B.

\section{Details regarding the timing of stimulus presentation Experiment 1}

Habituation: $600 \mathrm{~s}$ context exposure. Training: $120 \mathrm{~s}$ acclimation, interval between CS onsets is $180 \mathrm{~s}$, rat removed from context $120 \mathrm{~s}$ after last CS onset. Reactivation: $120 \mathrm{~s}$ acclimation, rat removed from context $60 \mathrm{~s}$ after CS onset. Test 1-2-3: $120 \mathrm{~s}$ acclimation, interval between CS onsets is $120 \mathrm{~s}$, rat removed from context $120 \mathrm{~s}$ after last CS onset.

\section{Experiment 2}

Training: $600 \mathrm{~s}$ acclimation, interval between CS onsets is $180 \mathrm{~s}$, rat removed from context $180 \mathrm{~s}$ after last CS onset. Reactivation: $120 \mathrm{~s}$ acclimation, rat removed from context $60 \mathrm{~s}$ after CS onset. Test 1-2: $120 \mathrm{~s}$ acclimation, interval between CS onsets is on average $120 \mathrm{~s}$ (range $100-140 \mathrm{~s})$, rat removed from context $120 \mathrm{~s}$ after last CS onset. Reinstatement: $300 \mathrm{~s}$ acclimation, interval between US onsets is $180 \mathrm{~s}$, rat removed from context $120 \mathrm{~s}$ after last US onset.

\section{Experiment 3}

Habituation: $600 \mathrm{~s}$ context exposure. Training: $120 \mathrm{~s}$ acclimation, 1 CS-US pairing, rat removed from context $60 \mathrm{~s}$ after CS onset. Reactivation: $120 \mathrm{~s}$ acclimation, 1 CS, rat removed from context $60 \mathrm{~s}$ after CS onset. Test 1-2-3: $120 \mathrm{~s}$ acclimation, 4 CSs and interval between CS onsets is on average $120 \mathrm{~s}$ (range 90-150 s), rat removed from context $60 \mathrm{~s}$ after last CS onset.

\section{Experiment 4}

Training: $480 \mathrm{~s}$ acclimation, 1 CS-US pairing, rat removed from context $60 \mathrm{~s}$ after CS onset. Reactivation: $120 \mathrm{~s}$ acclimation, $1 \mathrm{CS}$, rat removed from context $60 \mathrm{~s}$ after CS onset. Test 1: $120 \mathrm{~s}$ acclimation, 4 CSs and interval between CS onsets is on average $120 \mathrm{~s}$ (range 90-150 s), rat removed from context $60 \mathrm{~s}$ after last CS onset.

\section{Experiment 5}

Training: $600 \mathrm{~s}$ acclimation, interval between CS onsets is $180 \mathrm{~s}$, rat removed from context $180 \mathrm{~s}$ after last CS 
onset. Reactivation: $120 \mathrm{~s}$ acclimation, rat removed from context $60 \mathrm{~s}$ after CS onset. Test 1-2-3: $120 \mathrm{~s}$ acclimation, interval between CS onsets is on average $120 \mathrm{~s}$ (range 100-140 s), rat removed from context $120 \mathrm{~s}$ after last CS onset.

\section{Experiment 6}

Training: $600 \mathrm{~s}$ acclimation, interval between CS onsets is $180 \mathrm{~s}$, rat removed from context $180 \mathrm{~s}$ after last CS onset. Reactivation: $120 \mathrm{~s}$ acclimation, rat removed from context $60 \mathrm{~s}$ after CS onset. Test 1-2: $120 \mathrm{~s}$ acclimation, interval between CS onsets is on average $120 \mathrm{~s}$ (range $100-140 \mathrm{~s}$ ), rat removed from context $120 \mathrm{~s}$ after last CS onset. Reinstatement: $300 \mathrm{~s}$ acclimation, interval between US onsets is $180 \mathrm{~s}$, rat removed from context $120 \mathrm{~s}$ after last US onset.

\section{Experiment 7}

Habituation: $600 \mathrm{~s}$ context exposure (4-h interval between two contexts, counterbalanced order). Training: $300 \mathrm{~s}$ acclimation, rat removed from context $60 \mathrm{~s}$ after CS-US offset.

Reactivation: $300 \mathrm{~s}$ acclimation, rat removed from context $60 \mathrm{~s}$ after CS offset. Test STM-1-2: $300 \mathrm{~s}$ acclimation, interval between CS onsets is $90 \mathrm{~s}$, rat removed from context $60 \mathrm{~s}$ after last CS offset.

\section{Experiment 8}

Training: $300 \mathrm{~s}$ acclimation, rat removed from context $60 \mathrm{~s}$ after CS-US offset. Test 1-2: $300 \mathrm{~s}$ acclimation, interval between CS onsets is $90 \mathrm{~s}$, rat removed from context $60 \mathrm{~s}$ after last CS offset.

\section{Drugs}

\section{Propranolol}

In experiments 1-4, propranolol (Product P0884, SigmaAldrich, Overijse, Belgium) was dissolved in saline on the day of injection to obtain a solution of $10 \mathrm{mg} / \mathrm{ml}$, administered intraperitoneally at $1 \mathrm{ml} / \mathrm{kg}(10 \mathrm{mg} / \mathrm{kg}$ dose $)$. Control animals received saline $(1 \mathrm{ml} / \mathrm{kg})$. Injections were given in the testing room, except for experiment 4 where animals were injected in an adjacent room.

\section{Rapamycin}

In experiments 5-6, rapamycin (LC Laboratories, Woburn, MA, USA) was dissolved in vehicle (100\% DMSO) (99.8\% dimethyl sulfoxide extra pure, Acros Organics, Geel, Belgium) on the day of injection to obtain a solution of $20 \mathrm{mg} / \mathrm{ml}$, administered intraperitoneally at $1 \mathrm{ml} /$ $\mathrm{kg}(20 \mathrm{mg} / \mathrm{kg}$ dose in experiment 5) or $2 \mathrm{ml} / \mathrm{kg}$ (40 mg/ $\mathrm{kg}$ dose in experiment 6). Injections were given in the testing room.

\section{Anisomycin and cycloheximide}

In experiments 7-8, anisomycin (Product A9789, SigmaAldrich) $(50 \mathrm{mg} / \mathrm{ml})$ was dissolved in saline which was brought to $\mathrm{pH} \leq 5$ using $\mathrm{HCl}$, and then adjusted again to $\mathrm{pH} \pm 7-7.4$ with $\mathrm{NaOH}$. Cycloheximide (Product C7698, Sigma Aldrich) $(0.5 \mathrm{mg} / \mathrm{ml})$ and the vehicle solution were prepared using the same procedure. All solutions were made on the day before injection and stored in the fridge until $30 \mathrm{~min}$ before injection, while continuously being shielded from light. Solutions were administered subcutaneously in the nape of the neck at $3 \mathrm{ml} / \mathrm{kg}(150$ $\mathrm{mg} / \mathrm{kg}$ dose of anisomycin or $1.5 \mathrm{mg} / \mathrm{kg}$ dose of cycloheximide). Injections were given in a room adjacent to the testing room. Note that [9] used $2.8 \mathrm{mg} / \mathrm{kg}$ cycloheximide intraperitoneally, but mentioned the loss of several animals, which is why we decided to use a lower dose. The doses applied in this study are around the tolerance threshold (see Additional file 1), and these (or sometimes lower) doses have been shown to be effective in other rat learning procedures (e.g., [10, 12, 17, 67]).

Prior research (with anisomycin, [69]) moreover suggests that subcutaneous administration results in more longlasting effects than intraperitoneal injection, and may therefore produce inhibitory effects on protein synthesis that are more similar to those of intracerebral drug administration.

\section{Statistical analyses}

Statistical analyses were conducted using Statistica 13.5.0.17 (TIBCO Software Inc., Palo Alto, CA, USA), and the main analyses were confirmed in JASP 0.9.1 (JASP Team). Cohen's $d$ effect sizes were calculated according to [70] and power (with $\alpha=.05$ ) was estimated with $G^{*}$ Power 3.1.9.2 [71]. Significance levels were set at $p<.05$. All graphs were created using GraphPad Prism 7.02 (GraphPad Software, La Jolla, CA, USA).

\section{Preregistered analyses}

In experiments $1-7$, freezing during the reactivation CS was compared between drug-treated and control groups (two-sided $t$ tests) to assess whether all animals retrieved the fear memory to a similar extent. Next, the crucial analysis was a comparison of tone fear memory retention on test 1 (evaluation of freezing during the first $4 \mathrm{CSs}$ in experiments 1-6 and during the 3 CSs in experiment 7). Given the clear prediction of the direction of the effect (i.e., drug < control), one-sided $t$ tests were conducted on the average freezing during these CSs. When Levene's test suggested a violation of the equal variance assumption, Welch's $t$ test was performed (experiments 4 and 7). To consider all available information from each trial, we also conducted repeated-measures ANOVAs (RM ANOVAs) with factors Trial and Group, if necessary with Greenhouse-Geisser correction, and followed up with Tukey's post-hoc tests. Additionally, planned analyses 
regarding acute effects of anisomycin and cycloheximide on preCS and CS-elicited freezing during the short-term memory test (experiment 7) were performed (two-sided $t$ tests). As indicated above and in the graphs, most experiments continued after the (first) 3 or 4 CSs of test 1 , with the aim of evaluating the expected amnestic effect in more detail and over a longer period of time. Given the absence of any evidence for amnesia in drug-treated compared to control animals, reporting the results of all additional planned analyses (i.e., comparing the extent of spontaneous recovery, renewal and reinstatement between groups) seems superfluous. For the sake of completeness, all data are, however, shown in the graphs and the results of all preregistered analyses can be found on OSF. In none of these analyses significant group differences were found.

In experiment 8, the effect on consolidation of fear memory was evaluated by comparing freezing during the first 3 CSs of test 1 between drug-treated and control rats (RM ANOVA). Rats that had received vehicle after training $(n=12)$ were then allocated to two subgroups that received cycloheximide or vehicle after extinction training during test 1 . Extinction of both subgroups during test 1 (all 12 CSs) was evaluated with a RM ANOVA with Greenhouse-Geisser correction. Extinction memory retention (all $3 \mathrm{CSs}$ ) was analyzed with a RM ANOVA.

\section{Analyses that were not part of the preregistered analysis plan}

Given the results of the preregistered (frequentist inference) analyses of experiments 1-7, we conducted additional Bayesian analyses, using the BayesFactor package in $\mathrm{R}$ (version 3.3.2, $\mathrm{R}$ Foundation) and assuming a default Cauchy prior with a scaling factor of .707. In order to quantify the evidence for the absence of a group effect on average freezing during the tones at test, we performed Bayesian one-sided $t$ tests (drug $<$ control). In addition to tests per experiment, we carried out a Bayesian fixed-effects, one-sided meta-analysis using the $t$ values from one-sided $t$ tests (meta.ttestBF function). For all reported Bayesian analyses, $\mathrm{BF}_{01}$ quantifies evidence in favor of the absence of an amnestic effect (i.e., $\mathrm{H}_{0}$ : drug-treated rats do not show lower freezing than control rats at test). Bayes factors were categorized in accordance with [72], with a $\mathrm{BF}_{01}$ between 1 and 3 suggesting anecdotal evidence for $\mathrm{H}_{0}$, and $\mathrm{a} \mathrm{BF}_{01}$ between 3 and 10 suggesting substantial evidence.

To more comprehensively characterize the effects of the applied drugs, we also evaluated the acute effects of propranolol on freezing during the reactivation CS in experiment 4 (two-sided $t$ test, no exclusion criterion applied, thus $n=8$ per group). A similar analysis was done for acute effects of propranolol on freezing during an extinction session consisting of 12 CSs (RM ANOVA, Luyten et al. in prep). Long-term effects on body weight for rapamycin, anisomycin, and cycloheximide (experiments 5-7) were evaluated by comparing the increase in body weight (difference between last measurement before and after injection) between groups (two-sided $t$ tests).

For a more thorough analysis of extinction retention in experiment 8 , the change in freezing from the last trial of test 1 to the first trial of test 2 was evaluated with a RM ANOVA with factors test and group.

\section{Power calculations}

As mentioned above, published studies using propranolol, anisomycin or cycloheximide typically report large effect sizes. Intraperitoneal injection of $10 \mathrm{mg} / \mathrm{kg}$ propranolol after retrieval of a conditioned tone in adult male rats $[8$, 29 ] has repeatedly been found to produce strong amnestic effects with an average Cohen's $d=1.99$ (based upon inspection of the graphs of both studies), resulting in a power of .98 when comparing 8 propranolol and 8 control rats (all calculations are for one-sided $t$ tests, unless indicated otherwise). Power is still $>0.90$ with only 5 propranolol and 7 control animals, as is the case for experiment 4 .

Protein synthesis inhibitors anisomycin and cycloheximide have both been administered in auditory fear conditioning studies, albeit not systemically, but locally into the basolateral amygdala. They have, however, been applied systemically for example for interference with inhibitory avoidance memories in rats. For anisomycin, the effect size in $[4,10](150 \mathrm{mg} / \mathrm{kg})$ was $d=1.92$ on average. This results in a power of .99 when using a sample size of 10 rats per group. For cycloheximide, the effect size in $[9,28]$ was $d=1.29$ on average, resulting in a power of .94 with 14 cycloheximide-treated and 12 control rats.

Effect sizes in rat auditory fear conditioning studies using injections of mTOR inhibitor rapamycin (20-40 $\mathrm{mg} / \mathrm{kg}$ ) are considerably smaller (average $d=0.59$ in [11, $30,31])$. The sample sizes used in the current study $(n=$ 8 per group) do not allow for a power of $\geq .80$ (rather 0.30 ), but experiments with different doses of rapamycin do permit us to explore whether there is at least a trend supporting an amnestic effect.

In the final study, we investigated the effect of cycloheximide on the consolidation of fear memories. Published reports described significant interference of cycloheximide with the consolidation of tone fear memories (in rats and mice [35-37];), with $d=1.24$ on average, yielding a power of 0.83 with 12 animals per group (two-sided $t$ test). In a subset of animals $(n=6$ per group), we evaluated the effect of cycloheximide on the consolidation of an extinction memory. This analysis may be underpowered, although some prior studies did show very large effect sizes (e.g., [73], with systemic cycloheximide and contextual fear in mice, $d=1.77$ ), which would still yield acceptable power (0.79) with only 6 animals per subgroup (two-sided $t$ test). 


\section{Supplementary Information}

The online version contains supplementary material available at https://doi. org/10.1186/s12915-021-00957-x.

Additional file 1. Contains details about any adverse reactions to the applied drugs.

Additional file 2. Contains a supplementary discussion regarding indices of destabilization

Additional file 3. Contains an extra experiment that was performed prior to and for the selection of the behavioral procedure for Experiment

\section{Acknowledgements}

We thank Dr. Kelly Luyck for her technical assistance with the preparation of the anisomycin and cycloheximide solutions.

\section{Consent to participate}

Not applicable.

\section{Authors' contributions}

Conceptualization: L.L., T.B.; methodology: L.L., T.B.; validation: L.L.; formal analysis: L.L., N.S.; investigation: L.L., AE.S., N.S.; data curation: L.L.; writing—original draft: L.L.; writing—review and editing: L.L., AE.S., N.S., T.B.; visualization: L.L.; supervision: L.L., T.B.; project administration: L.L.; funding acquisition: T.B. All authors read and approved the final manuscript.

\section{Authors' information}

AE.S.'s current position is at KU Leuven, Laboratory for Biological Psychology, Leuven, Belgium.

\section{Funding}

We acknowledge the financial support of the European Research Council (ERC Consolidator Grant to T.B., grant number 648176).

\section{Availability of data and materials}

All data generated or analyzed during this study are included in this published article, its supplementary information files and publicly available repositories. The full dataset supporting the conclusions of this article is available in the Figshare repository, https://doi.org/10.6084/m9.figshare.c. 5258129 [74].

\section{Ethics approval and consent to participate}

This project (P234-2015) was approved by the animal ethics committee at $\mathrm{KU}$ Leuven and is in accordance with the Belgian and European laws, guidelines and policies for animal experimentation, housing, and care (Belgian Royal Decree of 29 May 2013 and European Directive 2010/63/EU on the protection of animals used for scientific purposes of 20 October 2010)

\section{Consent for publication}

Not applicable.

\section{Competing interests}

The authors declare that they have no competing interests.

Received: 8 December 2020 Accepted: 11 January 2021

Published online: 26 January 2021

\section{References}

1. Dudai Y. The neurobiology of consolidations, or, how stable is the engram? Annu Rev Psychol. 2004:55:51-86.

2. McGaugh JL. Memory--a century of consolidation. Science. 2000;287(5451): 248-51.

3. Misanin JR, Miller RR, Lewis DJ. Retrograde amnesia produced by electroconvulsive shock after reactivation of a consolidated memory trace. Science. 1968:160(3827):554-5.

4. Nader K, Schafe GE, LeDoux JE. Fear memories require protein synthesis in the amygdala for reconsolidation after retrieval. Nature. 2000; 406(6797):722-6.
5. Przybyslawski J, Roullet P, Sara SJ. Attenuation of emotional and nonemotional memories after their reactivation: role of beta adrenergic receptors. J Neurosci. 1999;19(15):6623-8.

6. Beckers T, Kindt M. Memory reconsolidation interference as an emerging treatment for emotional disorders: strengths, Limitations, Challenges, and Opportunities. Annu Rev Clin Psychol. 2017:13:99-121.

7. Debiec J, LeDoux JE, Nader K. Cellular and systems reconsolidation in the hippocampus. Neuron. 2002;36(3):527-38.

8. Debiec J, LeDoux JE. Disruption of reconsolidation but not consolidation of auditory fear conditioning by noradrenergic blockade in the amygdala. Neuroscience. 2004;129(2):267-72.

9. Gisquet-Verrier P, Lynch JF 3rd, Cutolo P, Toledano D, Ulmen A, Jasnow AM, Riccio DC. Integration of new information with active memory accounts for retrograde amnesia: a challenge to the consolidation/reconsolidation hypothesis? J Neurosci. 2015:35(33):11623-33.

10. Taubenfeld SM, Milekic MH, Monti B, Alberini CM. The consolidation of new but not reactivated memory requires hippocampal C/EBPbeta. Nat Neurosci. 2001;4(8):813-8

11. Tallot L, Diaz-Mataix L, Perry RE, Wood K, LeDoux JE, Mouly AM, Sullivan RM, Doyere $\mathrm{V}$. Updating of aversive memories after temporal error detection is differentially modulated by mTOR across development. Learn Mem. 2017; 24(3):115-22.

12. Flint RW Jr, Valentine S, Papandrea D Jr. Reconsolidation of a long-term spatial memory is impaired by cycloheximide when reactivated with a contextual latent learning trial in male and female rats. Neuroscience. 2007; 148(4):833-44

13. Kindt $M$, Soeter $M$, Vervliet B. Beyond extinction: erasing human fear responses and preventing the return of fear. Nat Neurosci. 2009:12(3):256-8.

14. Bos MG, Beckers T, Kindt M. Noradrenergic blockade of memory reconsolidation: a failure to reduce conditioned fear responding. Front Behav Neurosci. 2014:8:412.

15. Soeter M, Kindt M. An abrupt transformation of phobic behavior after a post-retrieval amnesic agent. Biol Psychiatry. 2015;78(12):880-6.

16. Gisquet-Verrier P, Riccio DC. Memory integration: an alternative to the consolidation/reconsolidation hypothesis. Prog Neurobiol. 2018;171:15-31.

17. Bernardi RE, Lattal KM, Berger SP. Anisomycin disrupts a contextual memory following reactivation in a cocaine-induced locomotor activity paradigm. Behav Neurosci. 2007:121(1):156-63.

18. Blundell J, Kouser M, Powell CM. Systemic inhibition of mammalian target of rapamycin inhibits fear memory reconsolidation. Neurobiol Learn Mem. 2008;90(1):28-35.

19. Fan HY, Cherng CG, Yang FY, Cheng LY, Tsai CJ, Lin LC, Yu L. Systemic treatment with protein synthesis inhibitors attenuates the expression of cocaine memory. Behav Brain Res. 2010;208(2):522-7.

20. Lattal KM, Abel T. Behavioral impairments caused by injections of the protein synthesis inhibitor anisomycin after contextual retrieval reverse with time. Proc Natl Acad Sci U S A. 2004:101(13):4667-72.

21. Milekic MH, Brown SD, Castellini C, Alberini CM. Persistent disruption of an established morphine conditioned place preference. J Neurosci. 2006;26(11): 3010-20.

22. Suzuki A, Josselyn SA, Frankland PW, Masushige S, Silva AJ, Kida S. Memory reconsolidation and extinction have distinct temporal and biochemical signatures. J Neurosci. 2004;24(20):4787-95.

23. Reichelt AC, Lee JL. Memory reconsolidation in aversive and appetitive settings. Front Behav Neurosci. 2013;7:118.

24. Wang SH, de Oliveira AL, Nader K. Cellular and systems mechanisms of memory strength as a constraint on auditory fear reconsolidation. Nat Neurosci. 2009;12(7):905-12.

25. Milekic $\mathrm{MH}$, Alberini $\mathrm{CM}$. Temporally graded requirement for protein synthesis following memory reactivation. Neuron. 2002;36(3):521-5.

26. Bustos SG, Maldonado H, Molina VA. Disruptive effect of midazolam on fear memory reconsolidation: decisive influence of reactivation time span and memory age. Neuropsychopharmacology. 2009;34(2):446-57.

27. Tronson NC, Taylor JR. Molecular mechanisms of memory reconsolidation. Nat Rev Neurosci. 2007:8(4):262-75

28. Duvarci S, Nader K, LeDoux JE. Activation of extracellular signal-regulated kinase- mitogen-activated protein kinase cascade in the amygdala is required for memory reconsolidation of auditory fear conditioning. Eur Neurosci. 2005;21(1):283-9.

29. Muravieva EV, Alberini CM. Limited efficacy of propranolol on the reconsolidation of fear memories. Learn Mem. 2010;17(6):306-13. 
30. Hoffman AN, Parga A, Paode PR, Watterson LR, Nikulina EM, Hammer RP Jr Conrad CD. Chronic stress enhanced fear memories are associated with increased amygdala zif268 mRNA expression and are resistant to reconsolidation. Neurobiol Learn Mem. 2015;120:61-8.

31. Li Y, Meloni EG, Carlezon WA Jr, Milad MR, Pitman RK, Nader K, Bolshakov WY. Learning and reconsolidation implicate different synaptic mechanisms. Proc Natl Acad Sci U S A. 2013;110(12):4798-803.

32. Barak S, Liu F, Ben Hamida S, Yowell QV, Neasta J, Kharazia V, Janak PH, Ron D. Disruption of alcohol-related memories by mTORC1 inhibition prevents relapse. Nat Neurosci. 2013;16(8):1111-7.

33. Mac Callum PE, Hebert M, Adamec RE, Blundell J. Systemic inhibition of mTOR kinase via rapamycin disrupts consolidation and reconsolidation of auditory fear memory. Neurobiol Learn Mem. 2014;112:176-85.

34. Li J, Kim SG, Blenis J. Rapamycin: one drug, many effects. Cell Metab. 2014 19(3):373-9.

35. Kochli DE, Thompson EC, Fricke EA, Postle AF, Quinn JJ. The amygdala is critical for trace, delay, and contextual fear conditioning. Learn Mem. 2015; 22(2):92-100.

36. Lay BPP, Westbrook RF, Glanzman DL, Holmes NM. Commonalities and differences in the substrates underlying consolidation of first- and secondorder conditioned fear. J Neurosci. 2018;38(8):1926-41.

37. Stiedl O, Palve M, Radulovic J, Birkenfeld K, Spiess J. Differential impairment of auditory and contextual fear conditioning by protein synthesis inhibition in C57BL/6N mice. Behav Neurosci. 1999;113(3):496-506.

38. Bartsch W, Sponer G, Dietmann K, Fuchs G. Acute toxicity of various solvents in the mouse and rat. LD50 of ethanol, diethylacetamide, dimethylformamide, dimethylsulfoxide, glycerine, N-methylpyrrolidone, polyethylene glycol 400, 1,2-propanediol and tween 20. Arzneimittelforschung. 1976;26(8):1581-3.

39. Blaiss CA, Janak PH. Post-training, but not post-reactivation, administration of amphetamine and anisomycin modulates Pavlovian conditioned approach. Neurobiol Learn Mem. 2007;87(4):644-58.

40. Hernandez PJ, Kelley AE. Long-term memory for instrumental responses does not undergo protein synthesis-dependent reconsolidation upon retrieval. Learn Mem. 2004;11(6):748-54.

41. Haubrich J, Crestani AP, Cassini LF, Santana F, Sierra RO, Alvares Lde O, Quillfeldt JA. Reconsolidation allows fear memory to be updated to a less aversive level through the incorporation of appetitive information. Neuropsychopharmacology. 2015;40(2):315-26.

42. Pitman RK, Milad MR, Igoe SA, Vangel MG, Orr SP, Tsareva A, Gamache K, Nader K. Systemic mifepristone blocks reconsolidation of cue-conditioned fear; propranolol prevents this effect. Behav Neurosci. 2011;125(4):632-8.

43. Schroyens N, Alfei JM, Schnell AE, Luyten L, Beckers T. Limited replicability of drug-induced amnesia after contextual fear memory retrieval in rats. Neurobiol Learn Mem. 2019;166:107105.

44. Sevenster D, Beckers T, Kindt M. Retrieval per se is not sufficient to trigger reconsolidation of human fear memory. Neurobiol Learn Mem. 2012;97(3): 338-45.

45. Rodriguez-Romaguera J, Sotres-Bayon F, Mueller D, Quirk GJ. Systemic propranolol acts centrally to reduce conditioned fear in rats without impairing extinction. Biol Psychiatry. 2009;65(10):887-92.

46. Chalkia A, Weermeijer J, Van Oudenhove L, Beckers T. Acute but not permanent effects of propranolol on fear memory expression in humans. Front Hum Neurosci. 2019;13:51.

47. Adamec R, Strasser K, Blundell J, Burton P, McKay DW. Protein synthesis and the mechanisms of lasting change in anxiety induced by severe stress. Behav Brain Res. 2006;167(2):270-86.

48. Hebert M, Licursi M, Jensen B, Baker A, Milway S, Malsbury C, Grant VL, Adamec R, Hirasawa M, Blundell J. Single rapamycin administration induces prolonged downward shift in defended body weight in rats. PLoS One. 2014;9(5):e93691.

49. Schultz W, Dickinson A. Neuronal coding of prediction errors. Annu Rev Neurosci. 2000;23:473-500.

50. Pedreira ME, Perez-Cuesta LM, Maldonado H. Mismatch between what is expected and what actually occurs triggers memory reconsolidation or extinction. Learn Mem. 2004;11(5):579-85.

51. Sevenster D, Beckers T, Kindt M. Prediction error governs pharmacologically induced amnesia for learned fear. Science. 2013;339(6121):830-3.

52. Ben Mamou C, Gamache K, Nader K. NMDA receptors are critical for unleashing consolidated auditory fear memories. Nat Neurosci. 2006;9(10): 1237-9.
53. Diaz-Mataix L, Ruiz Martinez RC, Schafe GE, LeDoux JE, Doyere V. Detection of a temporal error triggers reconsolidation of amygdala-dependent memories. Curr Biol. 2013;23(6):467-72.

54. Finnie PS, Nader K. The role of metaplasticity mechanisms in regulating memory destabilization and reconsolidation. Neurosci Biobehav Rev. 2012 36(7):1667-707.

55. Jarome TJ, Werner CT, Kwapis JL, Helmstetter FJ. Activity dependent protein degradation is critical for the formation and stability of fear memory in the amygdala. Plos One. 2011;6(9):e24349.

56. Theilmann W, Kleimann A, Rhein M, Bleich S, Frieling H, Loscher W, Brandt C. Behavioral differences of male Wistar rats from different vendors in vulnerability and resilience to chronic mild stress are reflected in epigenetic regulation and expression of p11. Brain Res. 2016;1642:505-15.

57. Schroyens N, Bender CL, Alfei JM, Molina VA, Luyten L, Beckers T. Postweaning housing conditions influence freezing during contextual fear conditioning in adult rats. Behav Brain Res. 2019;359:172-80.

58. Kindt M, van Emmerik A. New avenues for treating emotional memory disorders: towards a reconsolidation intervention for posttraumatic stress disorder. Ther Adv Psychopharmacol. 2016;6(4):283-95.

59. Button KS, loannidis JP, Mokrysz C, Nosek BA, Flint J, Robinson ES, Munafo MR. Power failure: why small sample size undermines the reliability of neuroscience. Nat Rev Neurosci. 2013;14(5):365-76.

60. Biedenkapp JC, Rudy JW. Context memories and reactivation: constraints on the reconsolidation hypothesis. Behav Neurosci. 2004;118(5):956-64

61. Schwabe L, Nader K, Wolf OT, Beaudry T, Pruessner JC. Neural signature of reconsolidation impairments by propranolol in humans. Biol Psychiatry. 2012;71(4):380-6.

62. Thome J, Koppe G, Hauschild S, Liebke L, Schmahl C, Lis S, Bohus M. Modification of fear memory by pharmacological and behavioural interventions during reconsolidation. Plos One. 2016;11(8):e0161044.

63. Vousden $\mathrm{GH}$. An assessment of reconsolidation blockade to disrupt memories relevant to psychiatric disorders [doctoral thesis]. UK: University of Cambridge; 2017

64. Luyten L, Schroyens N, Hermans D, Beckers T. Parameter optimization for automated behavior assessment: plug-and-play or trial-and-error? Front Behav Neurosci. 2014;8:28.

65. Vetere G, Piserchia V, Borreca A, Novembre G, Aceti M, Ammassari-Teule M. Reactivating fear memory under propranolol resets pre-trauma levels of dendritic spines in basolateral amygdala but not dorsal hippocampus neurons. Front Behav Neurosci. 2013;7:211.

66. Luyten L, Schroyens N, Luyck K, Fanselow MS, Beckers T. No effect of glucose administration in a novel contextual fear generalization protocol in rats. Transl Psychiatry. 2016;6(9):e903.

67. Wu CR, Lin LW, Wang WH, Hsieh MT. The ameliorating effects of LiuWei Dihuang Wang on cycloheximide-induced impairment of passive avoidance performance in rats. J Ethnopharmacol. 2007;113(1):79-84.

68. Zhang WN, Bast T, Feldon J. The ventral hippocampus and fear conditioning in rats: different anterograde amnesias of fear after infusion of $\mathrm{N}$-methyl-D-aspartate or its noncompetitive antagonist MK-801 into the ventral hippocampus. Behav Brain Res. 2001;126(1-2):159-74.

69. Wanisch K, Wotjak CT. Time course and efficiency of protein synthesis inhibition following intracerebral and systemic anisomycin treatment. Neurobiol Learn Mem. 2008;90(3):485-94.

70. Lakens D. Calculating and reporting effect sizes to facilitate cumulative science: a practical primer for t-tests and ANOVAs. Front Psychol. 2013;4:863.

71. Faul F, Erdfelder E, Lang AG, Buchner A. G*Power 3: a flexible statistical power analysis program for the social, behavioral, and biomedical sciences. Behav Res Methods. 2007;39(2):175-91.

72. Wetzels R, Matzke D, Lee MD, Rouder JN, Iverson GJ, Wagenmakers EJ. Statistical evidence in experimental psychology: an empirical comparison using 855 t tests. Perspect Psychol Sci. 2011;6(3):291-8.

73. Ryan TJ, Roy DS, Pignatelli M, Arons A, Tonegawa S. Memory. Engram cells retain memory under retrograde amnesia. Science. 2015;348(6238):1007-13.

74. Luyten L, Schnell AE, Schroyens N, Beckers T. Lack of drug-induced postretrieval amnesia for auditory fear memories in rats. Figshare. 2021. https:// doi.org/10.6084/m9.figshare.c.5258129.

\section{Publisher's Note}

Springer Nature remains neutral with regard to jurisdictional claims in published maps and institutional affiliations. 